Näyttely kutsuu ajattelemaan lapsuuden poliittista olemusta ja toimijuutta myös nykyyhteiskunnissa. Myös nykylapset elävät poliittisesti latautuneessa ympäristössä. Ei voi ajatella, että koska lapset ovat niin nuoria, he eivät ole poliittisesti hereillä tai vain hyväksyvät aikuisten ja ympäröivän yhteiskunnan arvot ja viestit. Nykyajan lapset elävät sekä ekokriisin aikaa että nationalismin ja populismin nousukautta, joten on tärkeää ymmärtää, kuinka lapset tulkitsevat ja toimivat näiden tapahtumien, haasteiden ja poliittisten suuntausten ristiaallokossa. On myös toivottavaa, että tällä näyttelyllä on sukupolvia yhdistävä vaikutus ja, että näyttelyyn tulleet ja tulevat lapsiasiakkaat kiinnostuvat kysymään vanhempiensa lapsuudesta ja jäävät janoamaan tarinoita.

Sosialistinen lapsuus -näyttely on syntynyt yhteistyössä Lenin-museon ja Tampereen yliopiston kasvatustieteiden tiedekunnan professorien, Zsuzsanna Millein ja Nelli Piattoevan kanssa. Tavoitteena on vielä jatkaa ja mahdollisesti

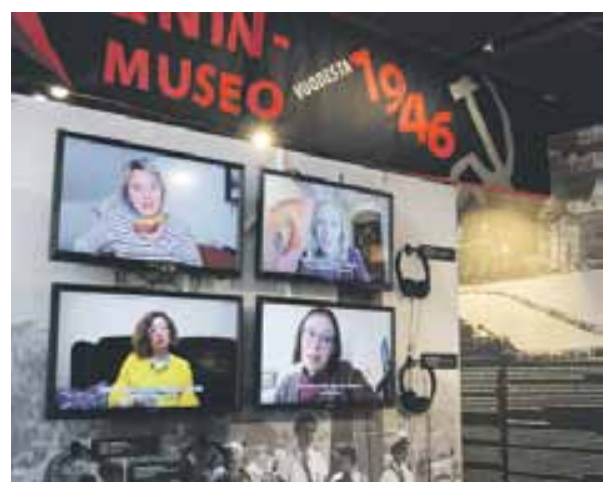

Sosialistisen lapsuuden eläneet tutkijat kertovat näyttelyssä omista lapsuuden kokemuksistaan ja muistoistaan. Kuva: Mia Heinimaa.

laajentaa monialaista ja hedelmällistä yhteistyötä lapsuus-teeman parissa.

Mia Heinimaa \& Nelli Piattoeva

\title{
Eduard Uspenskia muisteltiin Helsingissä
}

Yksi maailmanlaajuisesti tunnetuimmista venäläisistä lastenkirjailijoista, Eduard Uspenski (1937-2018) kuoli viime vuonna. Hänen luomansa ikoniset hahmot, kuten Tšeburaška ("Muksis") ja Krokotiili Gena, ovat tuttuja lapsille ympäri maailman. Uspenski oli myös hyvin suosittu Suomessa, ja myös meillä hänet muistetaan ennen kaikkea Fedja-setä, kissa ja koira -kirjan (Djadja Fjodor, pjos i kot, 1974, suom. 1975) kirjoittajana. Viime keväänä Helsingissä järjestettiin kaksi tilaisuutta, jotka oli omistettu Uspenskille sekä hänen suomalaiselle elämäkerran kirjoittajalleen, Hannu Mäkelälle. 13.2.2019 pidettiin Helsingin yliopiston Venäjä-seuran järjestämä lukupiiri ja19.3.2019 kirjallisuusilta, jonka Venäjä-seura järjesti yhteistyössä Käpylän Družba -järjestön sekä Käpylän kirjaston ja kirjastoyhdistyksen kanssa.

Kansalliskirjastossa kokoontuneen Venäjätietokirjallisuuden lukupiirin osallistujille Fedjasetä oli tuttu hahmo omasta lapsuudesta tai nuoruudesta. Kohtaus, jossa posteljooni Petškin tuo ovelle Pörriäisen on saanut jo monta sukupolvea ulvomaan naurusta yhdessä niin kirjan kuin näytelmänkin muodossa. Slaavilaisen kirjaston Irma Reijonen nosti lempikirjanaan esille myös Uspenskin vähemmän tunnetun romaanin Takuumiehet (Garantijnyje tšelovetški, 1975, suom.
1978). Kaikkein parhaiten osallistujat kuitenkin muistivat Uspenskiin liittyen "Krokotiili Genan syntymäpäivälaulun", joka Suomessa tunnetaan myös nimellä "Minä soitan harmonikkaa". M. A. Nummisen tulkinnan tunnistaa varmasti jokainen vaikkei olisi Uspenskista tai Genasta koskaan kuullutkaan.

Lastenkirjojen ja -laulujen sijaan lukupiirin varsinaisena aiheena oli kuitenkin Hannu Mäkelän Eetu (Tammi, 2008). Kirjassa Mäkelä kertoo Uspenskin elämästä, tuotannosta ja kahden kirjailijan välisestä ystävyydestä. Hannu Mäkelä on laajassa kirjallisessa tuotannossaan ennenkin lähestynyt elämäkertakirjoittamista. Finlandia-palkinnon saanut Mestari. Eino Leinon elämä ja kuolema (1995) kokeili tietokirjan ja romaanin rajapintaa onnistuneesti. Eetukaan ei ole perinteinen elämänkerta, mutta tällä kertaa näkökulma ei ole romaanikirjailijan vaan ystävän ja kirjailijakollegan. Myös kirjankustannusala nousee mielenkiintoisella tavalla keskiöön, sillä Mäkelä tutustui Uspenskiin alun perin työskennellessään Otavalla.

Kirjassa onkin hulvaton kuvaus siitä, miten Mäkelä tutustui Uspenskiin ensimmäisen kerran 1970-luvun puolivälissä osallistuessaan Otavan suomalaisdelegaatiossa Moskovan kirjallisuusmessuille. Detskaja literatura ("Lastenkirjal- 
lisuus") -kustantamon päällikön audienssilla Mäkelä kysyy reippaasti venäjäksi "Mikä on tällä hetkellä tiedän paras kirjanne?" Hetken mietittyään tympeä johtaja pyytää assistenttiaan noutamaan Fedja-sedän. Anelusta huolimatta Mäkelä ei kuitenkaan saa kirjaa omakseen, koska se on johtajan mukaan ainoa kappale kirjaa. Mäkelä heittäytyy polvilleen ja rukoilee: Možno? ('Saanko?") Loppu on sitten Suomen lastenkirjallisuuden ja lukemisen historiaa.

Tämä sattuma ja se, että Hannu Mäkelä saman tien hotellissa kirjan ahmaistuaan hullaantui täysin Fedjaan, on vastuussa Uspenskin esittelystä suomalaiselle lukijakunnalle. Sittemmin Mäkelä sai Otavan julkaisemaan Uspenskin kaikki keskeiset teokset Martti Anhavan suomennoksina. Fedjan jälkeen julkaistiin Uspenskin esikoinen Krokotiili Gena ja hänen ystävänsä (Krokodil Gena i ego druzja, 1966, suom. 1977), sekä Takuumiehet (Garantijnije tšelovetški, 1975, suom 1978) ja Alas taikavirtaa (Vniz po volšebnoi reke, 1971, 1980). Useamman yrityksen jälkeen onnistui vihdoin myös itse kirjailijan tapaaminen, mistä alkoivat vuosikymmenten läpi jatkunut ystävyys sekä molemminpuoliset vierailut rajan yli. Uspenskin onnistui saada kirjojaan julki Neuvostoliitossa melko harvakseltaan, sillä Mäkelän mukaan hän ei omaperäisenä ajattelijana - ja omapäisenä henkilönä - ollut oikeiden piirien suosiossa. Neuvostoliiton romahtamisen jälkeen Uspenskin tilanne helpottui, ja 1990-luvulta alkaen hän julkaisikin toistakymmentä jatko-osaa sekä Genan että Fedjan tarinalle. Fedja-setä -kirjoista yhteensä seitsemän on käännetty myös suomeksi.

Mäkelä mainitsee useaan otteeseen kirjassaan, että vaikka Uspenskilla olikin Neuvostoliitossa välillä vaikea saada kirjojaan julki, töitä kuitenkin riitti käytännössä kaikkialla muualla: teatterissa, radiossa, televisiossa ja elokuvassa. Hän oli esimerkiksi mukana suunnittelemassa vuodesta 1964 asti televisiossa pyörineen lasten iltaohjelman Spokoinoi notši, malyši ("Hyvää yötä pikkuiset") alkutaivalta, sekä veti 1990- ja 2000-luvuilla suosittua radio-ohjelmaa $V$ našu gavan zahodili korabli ('Laivat ovat saapuneet satamaan"), jossa kuulijat saivat soittaa ja toivoa - ja laulaakin - itselleen tärkeitä, mutta aiemmin kiellettyjä lauluja.

Venäjällä Uspenski tunnetaan kuitenkin ennen kaikkea hänen kirjojensa pohjalta tehtyjen animaatioelokuvien kautta. Suurimman jäljen Neuvostoliiton lastenkulttuuriin on jättänyt erityisesti kirjan Krokotiili Gena ja hänen ystävänsä pohjalta tehdyt kolme nukkeanimaatiota (1969-1947). Jokaisessa näistä pienistä eloku- vista kuullaan vähintään yksi laulu, joista se kaikkein kuuluisin kuullaan trilogian toisessa osassa Tšeburaška (1971, suom. esitetty nimellä Appelsiinipoika, 1978). "Krokotiili Genan laulu" on melko ironisesti myös ainoa, jonka sanoista ei vastaakaan Uspenski vaan runoilija ja lastenkirjailija Aleksandr Timofejevski.

Fedja-setä, kissa ja koira puolestaan on neuvostoaikana ikuistettu peräti kahteen eri animaatiotrilogiaan. Näistä ensimmäinen on kolmeen itsenäiseen 20-minuuttiseen osaan jakautunut Djadja Fjedor, pjos $i$ kot, joka valmistui vuosina 1975-1976 ja sen ohjasivat Studio Ekranille Juri Klepatski ja Lidia Surikova. Paljon tunnetumpi on Sojuzmultfilmin muutamaa vuotta myöhemmin tekemä Troje iz Prostokvašino (Kolme kaveria Piimälästä, 1978) ja sen jatko-osat. Mielenkiinoista näissä jälkimmäisissä on se, että jokaisessa kolmessa päähenkilö on hieman erinäköinen, eri lailla piirretty, vaikka muiden hahmojen ulkomuoto säilyy suurin piirtein samana. Tämä johtaa pohtimaan, että Venäjällä itse Fedja-sedän hahmo ei ole ihan samanlainen brändi kuin Suomessa, kirjan tapahtumapaikka ja muut hahmot - varsinkin kissa ja koira - ovat olennaisempia.

Käsikirjoittamisen lisäksi Eduard Uspenski toimi myös lastenkirjallisuuden kääntäjänä: hänen muokkaamanaan Neuvostoliitossa ilmestyi myös Hannu Mäkelän kontribuutio lasten suosikkihahmojen kirjoon. Herra Huu ilmestyi nimellä Djadjuška $A u$ ja tämänkin luomuksen pohjalta Uspenski oli mukana tekemässä nukkeanimaatiotrilogiaa, joka ilmestyi vuonna 1979. Uspenski oli ottanut paljonkin taiteilijan luovia vapauksia käännöstä ja käsikirjoitusta tehdessään, mutta Hannu Mäkelä on silti kiitollinen naapurimaassa saamastaan huomiosta ja uudesta yleisöstä: "Kirja on myös hiljattain käännetty uudestaan, hieman uskollisemmin nimellä Strašnyi gospo$\operatorname{din} A u$. Neuvostoaikana herra-sanaa ei voinut käyttää, siksi Eetu nimesi hahmon 'djadjuškaksi' - eli sedäksi”, Mäkelä kertoo Käpylän kirjaston Uspenski-illan pääpuhujana vieraillessaan.

Kirjastoillan aikana Mäkelä kertoo elävästi myös Herra Huun neuvostovalloituksen seurauksena ilmestyneen papukaija Stasikin tarinan. Se on myös yksi Eetu-kirjan hersyvimpiä lukuja: impulsiivisella ja vahvatahtoisella Uspenskilla oli selkeä visio, että Mäkelän tienaamat palkkiot Herra Huun menestyksestä Neuvostoliitossa olisi kaikkein järkevintä sijoittaa ostamalla torilta siellä myynnissä ollut eksoottinen papukaija. "Se on sijoitus, jossa ei voi hävitä. Sen arvo vain kasvaa ajan myötä'. Uspenskin ajatus oli, että opettamalla lahjakkaan papukaijan puhumaan 
ja matkimaan siitä voisi tulla suuri maailmanlaajuinen menestys sirkuksessa. Harmillisesti vain papukaija ei Uspenskin hoidossa opikaan ihmeellisiä taitoja odotetulla tavalla - ja se löytää lopulta uuden kodin anopin luota. Tarinassa tapahtuu vielä loppukäänne, jossa anopin palauttama papukaija oppii kuin oppiikin matkimisen jalon taidon - ja herättää Mäkelän aamuyön tunteina moskovalaisessa kerrostaloasunnossa jäljittelemällä erehdyttävästi työskentelemään ryhtyneen kirjailijan kirjoituskoneen ääntä.

Yleisö pyytää Mäkelää nimeämään lempikirjansa Uspenskin tuotannosta. Sitä ei tarvitse pitkään miettiä: Mäkelän oma suosikki on edelleen ensimmäinen Fedja-setä. Tähän on yleisön helppo yhtyä.

"Sen tasoisen kirjan tekee kirjailija vain yhden elämässään", Käpylän kirjastoyhdistyksen Marja-Leena Mikkola vahvistaa. "Onnittelut sinulle ja suuri onni meille kaikille suomalaislukijoille, että löysit sen kirjan".

Mäkelä tietää hyvin myös Fedja-sedän syntytarinan. Kirjassaan hän kertoo, kuinka Uspenski oli kirjoittanut hahmon alun perin aikuiseksi, mutta mentorina toiminut vanhempi kirjailija kehotti tekemään Fedjasta lapsen. Erinomainen veto on tietenkin se, että setä-nimitys jäi ennalleen ja se onnistuukin kuvamaan hahmoa aika oivallisesti: pikkuvanha Fedja on sangen onnellinen pieni mies. Toisin kuin vaikka Lindgrenin Peppi, joka suunnattomassa vapaudessaan ja anarkiassaan kuitenkin loppujen lopuksi kaipaa vanhempiaan ja huolenpitoa. Fedja puolestaan pärjää itsenäisessä elämässään melko hyvin, keskittyen tekemään aika vastuullisia valintoja. Mäkelän mukaan Fedjan suosion salaisuus on kirjassa kuvattu vapauden kokemus ja kaipuu siihen jokainen lapsi ja aikuinen voi samaistua.

Mäkelällä on myös oma arvionsa siitä, miksi Krokotiili Genan suosio ei ole meillä Suomessa kasvanut aivan samoihin mittoihin: "Krokotiili Genassa byrokratian kritiikki on keskiössä, suuri osa sen huumorista perustuu neuvostotodellisuuden kustannuksella pilailuun. Se ei ole ehkä tuntunut niin tärkeältä meillä”.

Mäkelän mukaan parasta Uspenskin kirjoissa on arvaamattomuus. Kun alkaa lukea, ei voi tietää kuinka tarina päättyy. "Sitä samaa on myös Tove Janssonin Muumi-kirjoissa. Siksi Uspenski ihaili niitä ja arvosti suuresti Janssonia”, Mäkelä toteaa.

Eetu on ensimmäinen ja toistaiseksi ilmeisesti ainoa Eduard Uspenskista kirjoitettu kirja. Se kertoo ehkä jotain siitä hieman ailahtelevaisesta asemasta joka Uspenskille neuvostoaikana ehti muodostua. Varmasti se kertoo myös jotain siitä, miten lastenkulttuurilla ylipäänsä ei ole kovin suuri huomioarvo meidän aikuisten maailmassa. Mäkelä paljastaa, että teos on kuitenkin käännetty myös venäjäksi nimellä Edik vuonna 2008. Eetu-kirjan kirjoittaminen on siten ollut suuri kulttuuriteko rajan molemmin puolin. Kirjailija Uspenski on jo poissa, mutta hänen kirjoituskoneensa ääni kaikuu edelleen.

Ira Österberg

\section{Pohjoismaiden slavistit koolla Joensuussa}

Pohjoismainen slavistikongressi (Nordiska Slavistmötet) järjestettiin 21. kerran Joensuussa 14.-18.8.2019. Kolmen vuoden välein järjestettävän konferenssin juuret juontuvat 1950-luvulle saakka, samoin kuin Nordiska slavistförbundetin kansainvälisesti arvostetun, vertaisarvioidun Scando-Slavica -lehden. Aiemmin slavistikongressi on järjestetty Suomessa Turussa, Helsingissä ja Tampereella. Tällä kertaa tapahtuma keräsi kokoon reilut sata slavistiikan alan tutkijaa. Heistä noin kolme neljäsosaa saapui Pohjoismaista, lisäksi osallistujia tuli Venäjältä sekä pienempi joukko myös muualta Euroopasta ja Pohjois-Amerikasta. Tapahtuma keräsi kokeneempien tieteentekijöiden ohella yhteen myös kiitettävästi alan väitöskirjatutkijoita.
Itä-Suomen yliopiston ja Suomen slavistipiiri ry:n järjestämässä tapahtumassa kuultiin monipuolisia esitelmiä eri slaavilaisiin kieliin ja kulttuureihin liittyen. Plenaariesitelmien ja rinnakkaissessioiden lisäksi konferenssin ohjelmaan kuului iltaohjelmaa, vierailu Joensuun taidemuseo Onnissa, Nordiska slavistförbundetin ja sen jäsenjärjestöjen kokouksia sekä retki Kolin kansallispuistoon. Konferenssin kielipaletti oli moninainen: ruotsin, venäjän ja englannin ollessa pääasiallisia käyttökieliä mukana olivat myös mm. norjan- ja ukrainankieliset esitelmät. Monikielisyys heijastui paitsi kahvitauoilla ja illallisilla myös paneelien koostumuksessa.

Esitelmissä tutkimusaiheiden kirjo ulottui kirjallisuudesta morfologiaan, historiasta kään- 